INTELLECTUALS AND THEIR PUBLICS

Comment on Panel on "Fame, Myth-Making, Authority, and Public Intellectuals," U.S. Intellectual History Conference, New York, 21 October 2010.

Faced with the daunting task of crafting a coherent comment on these three papers, which engage disparate subjects across a century's time and, on the face of it, speak to one another in, at best, muted tones, I have taken the coward's way out and not even tried. Rather I will use my time to suggest some of the ways that each begins to contribute to the wider project of writing the history of "Intellectuals and Their Publics," the theme of our conference.

\title{
Intellectuals
}

I want principally address the matter of "publics" and of intellectuals relationship to them, but let me say a word about "intellectuals." In my view, the now apparently unavoidable term, "public intellectual," is a baleful locution. It is a pleonasm. I know that Russell Jacoby put the term into wide circulation in order to distinguish favorably between intellectuals and academics, but in suggesting 
that academics qua academics are by implication "nonpublic" intellectuals, he gave them the satisfaction of believing that as academics they are, even in some diminished sense, intellectuals. ${ }^{1}$ They are not.

That arena of operation for intellectuals is the "public," which is why "public intellectual" is a pleonasm. Intellectuals are brain-workers who self-consciously craft their work for their fellow citizens gathered in often fluid publics far more extensive and unstable than academic disciplines and deliver arguments on matters of shared moment to these audiences. If you can reasonably expect that thirty other people who shop with you at Wegmans, or wherever it is you buy your groceries, might well want to read whatever it is you are working on, then you are an intellectual. If not, not. If they can get hold of your work at Wegmans, all the better.

This is not to say that an academic or other brainworker cannot also be an intellectual but most (of us) are not. Israel Zangwill was an intellectual. Leo Strauss and J. Robert Oppenheimer were, mostly, not. Noam Chomsky, the

1 Russell Jacoby, The Last Intellectuals: American Culture in the Age of Academe (New York: Basic Books, 1987). Note that Jacoby did not title his book "The Last Public Intellectuals," and he might have been better off avoiding the term, an exaggeration though his argument was. 
author of American Power and the New Mandarins, is an intellectual. Noam Chomsky, the author of Syntactic Structures, is not. When my Rochester colleague Allen Orr publishes an article in Genetics on "Segregation distortion in hybrids between the Bogota and USA subspecies of Drosophila pseudoobscura," he is not an intellectual. When he publishes a piece on "creationism" in The New York Review of Books, he is.

I realize that these stipulations might create some confusions for intellectual historians. We are not only historians of intellectuals but of all brain-workers and the artifacts and commodities they produce. We are historians of all explicit arguments and biographers of all those who make them. We might write a history of anti-war intellectuals in which the first Chomsky figures prominently, or one on popular debates over evolution in which orr has a part. Or we might write a history of linguistics or evolutionary biology in which the second Chomsky and the first Orr figure just as prominently.

Academic historians generally are perhaps more likely than those in other disciplines to think without warrant of themselves as intellectuals. This is because it is easier for us to take on this role if we wish: most of us write in 
something approximating the vernacular, and some of us even find our way to trade publishers. Wide-readership is among us an occasion for envy rather than suspicion. We can be found regularly in the pages of the New Republic and $\mathrm{Na}-$ tion, and even the New Yorker. Of course, because we have not armed ourselves with mystifying methodologies and secret linguistic handshakes, we also find ourselves with low bars to entry into the guild. Hence, many more historians than physicists or economists are not academics at all.

But even most academic historians cannot pass the Wegmans test. In my department of nineteen faculty, three of us might, sometimes, pass this test. The grade average of intellectual historians is even lower than those in other subspecialties. We all want to be Luke Menand (not an academic historian, incidentally), but we may as well aspire to be Oprah.

\section{Intellectual Formations}

My friend, Jean-Christophe Agnew, teaches a wonderful

course at Yale titled "U.S. Intellectual Formations in the Twentieth Century." By "intellectual formations," he means those social institutions and practices--"schools, disciplines, networks, communities, social worlds, cultural 
fronts, etc."--into which intellectuals and other brain workers have been embedded in the United States in the last century. He examines not only the anatomy and physiology of these formations but also "the ideas these formations produced and promoted to frame agendas in politics, science, social science, and the arts."

In other words, J-C is taking more seriously and systematically than most of we intellectual historians have done Christopher Lasch's injunction of fifty years ago to consider "the intellectual as a social type." ${ }^{2}$ This strikes me as a project in which more intellectual historians might join, not only when we write about intellectuals but also when we consider the work of other brain-workers. We could use a stronger dose of social history in our intellectual history.

Considerable strides in this regard have, of course, been made in the history of academic brain workers. ${ }^{3}$ But this is too easy. There we are anthropologists writing about our own or, at best, neighboring tribes. We need more

2 Christopher Lasch, The New Radicalism in America, 1889-1963: The Intellectual as Social Type (New York: Knopf, 1965).

3 I will cite but one splendid example: William Clark, Academic Charisma and the Origins of the Research University (Chicago: University of Chicago Press, 2006). For a view from a leading sociologists, see Pierre Bourdieu, Homo Academicus (Stanford: Stanford University Press, 1988). 
often to venture further afield and explore the intellectual formations that have shaped more distant natives, including intellectuals. ${ }^{4}$ Those intellectual historians who work on intellectuals could do more to embed their stories in the social history of the public sphere, tying their subjects and their ideas more closely to the means of cultural production and the formations that enclosed them there. ${ }^{5}$

Let me briefly point to some of the features of the papers we have heard today that seem to me to suggest the promise of this sort of inquiry.

\section{Zangwill}

A great deal of the work of intellectuals is performative, and we need to be fully attentive to this dimension of their speech acts. The public sphere is a public stage. The papers by Erik Greenberg and David Hecht bring this out nicely

\footnotetext{
4 The sociologist of choice for this project is probably Bourdieu. See perhaps especially his Distinction (Cambridge: Harvard University Press, 1984).

5 If I may, I would cite as exemplary a fine new book by one of my own students: Robert Vanderlan, Intellectuals Incorporated: Politics, Art, and Ideas Inside Henry Luce's Media Empire (Philadelphia: University of Pennsylvania Press, 2010).
} 
Fame is the coin of access by intellectuals to the public sphere. Israel Zangwill played on his fame, but, as Greenberg shows, his fame also played on him. As Leo Braudy has said in a remark that Greenberg quotes, "the heart of what it [means] to go public [is] to be entrapped by the gaze of others, to be reduced by their definitions" (2). As Greenberg says, Zangwill self-consciously shaped his public performances, but he was often unable to avoid being shaped by his audiences response to them. Intellectuals are often trapped not only by their last performance, but also by the reviews of their last performance.

Sponsored mobility and mutual back-scratching is also an important part of intellectuals' practice. Greenberg demonstrates that Zangwill was an important player in an international ethnic intellectual formation, and he points up some of the ways in which his career was tightly nestled within this formation. ${ }^{6}$

${ }^{6}$ Greenberg's paper also reminds us that the public sphere in which intellectuals intervene can in any given instance take on transnational dimensions. See the imaginative Pascale Casanova, The World Republic of Letters (Cambridge: Harvard University Press, 2007). 


\section{Oppenheimer}

Like Zangwill, J. Robert Oppenheimer was, as David Hecht shows, "actively involved in the production and use of his own image," once that image was part of the currency of the public marketplace of ideas. The point that Hecht would drive home to us--and he does it well--is that once in the public sphere, Oppenheimer, in order to survive, had to adopt some of the existing rhetorical conventions, especially the narrative forms, of this arena. He shows how oppenheimer, in his important 1954 New York Times selfdefense, made adroit use of the widespread clichés of "coming of age," "conversion," and "confessional" narratives, as well as the ever ready appeal of the habits of the heart.

As Hecht shows, this performative strategy was effective in winning Oppenheimer sympathy from readers. But, of course, in the end, he failed to win back his security clearance. No doubt in his larger study, Hecht will analyze with equal skill, the counter-narratives and rhetorical conventions that proved availing in bringing oppenheimer down. 
$\underline{\text { Strauss }}$

The term "intellectual" derives from the Dreyfus Affair in France, and it had then a clear political valence that it less clearly retains. Insofar as it is an honorific term, and it has been honorific in some quarters, even in the United States, it is so on the left (which is why so many academics, also mostly on the left, embrace it). This is not to say that there are no conservative or right-wing intellectuals. There most certainly are. But it is not a term conservatives usually attach to themselves. Indeed, more often than not their conservatism is marked by a deep hostility to intellectuals. It is as if they believe there would be no need for conservative intellectuals if someone in a good society did not have to worry about left-wing intellectuals and keep them in line in their own arena of operation. ${ }^{7}$ Since the stakes are high, conservative intellectuals are willing to risk the irony of calling for the marginalization of a group to which they themselves belong.

Leo Strauss provided postwar American conservatives with a epistemological and metaphysical underpinning for this hostility to intellectuals, and a number of neo-

7 See, for example, Richard Posner, Public Intellectuals: A Study of Decline (Cambridge: Harvard University Press, 2001). 
conservatives made it a staple of their ideology.

Strauss, as Barry Wurgaft says, was a "private intellectual

par excellence" (2), that is by my lights, not an intellec-

tual at all but a scholar. But his views influenced neoconservative intellectuals such as Irving Kristol who were unabashed in attacking intellectuals as a pivotal element a nefarious professional-managerial "new class," of which the neoconservatives themselves were, of course, a part. ${ }^{8}$

In turn, it should be said, there is no group of brain-workers that intellectuals distrust more than those "para-intellectuals" who do a dramatic imitation of an intellectual while serving a repressive state. This includes most of the Bushy neo-conservatives Wurgaft lists:

Wolfowitz, Perle, Feith, and so forth. ${ }^{9}$ Nothing annoys many intellectuals more than the continued prominence of Henry Kissinger on lists of "public intellectuals." It is one thing to have a pack of liars on the list (and here, in all fairness, we must include not only the neoconservatives but

8 See my "The Counter-Intelligentsia," Linguafranca (November 1996): 6571 .

9 William Kristol is an interesting case in that he among his generation of neo-conservatives he has served to mediate the relationship between intellectuals and the para-intellectuals in Washington. I do not recall where I heard or read it, but at some point in the early nineties, someone said that in moving from Irving to Bill Kristol, neoconservatism had shifted its favored form from the elegant essay to the fax. 
Arthur Schlesinger, Jr. and others to their left); quite another to admit a war criminal to its top ranks, one whose most damaging work was neither public nor that of an intellectual. ${ }^{10}$

All this is to say that one of the most significant matters debated in the public sphere, by intellectuals and others, is the political role of intellectuals. As Wurgaft nicely puts it, "The stories we tell about public [sic] intellectuals can become useful barometers of our political hopes and fears." 11

The study of intellectual formations is an academic one. One cannot expect to gain much traction as an intellectual doing this sort of scholarly work. Nonetheless, one of the few audiences outside their discipline that academic historians might hope to cultivate is that of intellectuals (most of whom are themselves academics).

Some of those intellectuals will, no doubt, draw lessons from such work in order to advance their careers

\footnotetext{
10 See Christopher Hitchens, The Trial of Henry Kissinger (New York: Verso, 2002).

11 Here I will again shamelessly note the work (in progress) of another of my students: Michael Brown, "Experts, Eggheads, and Elites: Debating the Role of Intellectuals in American Political Culture, 1952-2008" (PhD Dissertation: University of Rochester).
} 
within the public sphere as currently constituted. Others, however, might find such histories useful in further transforming that sphere. In any case, any work that disabuses intellectuals of the notion that they are independent and "free-floating" is probably worth our while. We may then await with interest the further work of my fellow panelists.

Robert Westbrook 